This item was submitted to Loughborough's Research Repository by the author.

Items in Figshare are protected by copyright, with all rights reserved, unless otherwise indicated.

\title{
Domination and disobedience: Protest, coercion and the limits of an appeal to justice
}

\section{PLEASE CITE THE PUBLISHED VERSION}

https://doi.org/10.1017/s1537592718001111

\section{PUBLISHER}

Cambridge University Press (CUP)

\section{VERSION}

AM (Accepted Manuscript)

\section{PUBLISHER STATEMENT}

This paper was accepted for publication in the journal Perspectives on Politics and the definitive published version is available at https://doi.org/10.1017/s1537592718001111

\section{LICENCE}

CC BY-NC-ND 4.0

\section{REPOSITORY RECORD}

Aitchison, Guy. 2018. "Domination and Disobedience: Protest, Coercion and the Limits of an Appeal to Justice”. Loughborough University. https://hdl.handle.net/2134/15059709.v1. 


\title{
Domination and Disobedience: Protest, Coercion and the Limits of an Appeal to Justice
}

\author{
Dr. Guy Aitchison \\ g.aitchison@lboro.ac.uk \\ Published in: Perspectives on Politics, Volume 16, Issue 3
}

(Note: This is a pre-publication draft. Please refer to the published version.)

I offer a conceptual framework for assessing the normative legitimacy of coercive disobedience - involving threats, disruption, force, and deceit-by social movements. A standard liberal view is that while coercion may be required to resist authoritarian regimes, it is illegitimate in a democratic state since it conflicts with majority rule and mutual respect. In restricting disobedience to a form of moral persuasion, this perspective neglects how social power and material interests can distort the conditions for open, fair deliberation. I offer a principled defense of coercive disobedience, not only in repressive states but in plausibly democratic societies. I argue that coercion can be justified on democratic republican grounds as a means to collectively contest objectionable forms of political domination. The use of coercion can be justified as a surrogate tool of political action for those who lack effective participation rights; as a remedial tool to counteract the dominating influence of powerful actors over the process of democratic will formation, and as a mobilizational tool to maintain participation and discipline in collective action. I conclude by proposing democratic constraints on the use of coercive tactics designed to offset the potential movements themselves become a source of arbitrary power.

Is it justified for political movements to pursue their goals by means of threats, coercion and deception? This question has become the subject of renewed controversy following an upsurge in vigorous - occasionally violent - forms of political activity by protest movements. In recent years, we have seen the occupation of sacred lands by environmental and indigenous rights activists to prevent fracking, the frustration of immigration enforcement measures with false reports, disruptive street protests, squatting movements and 'political' strikes by workers against austerity and labour market reforms. A standard liberal view in the philosophical literature is that while the use of coercive tactics may be required in authoritarian regimes it is not appropriate in democratic states with a 
broadly egalitarian ethos. Under this perspective, the principal role of disobedience is persuasive: through dramatic acts of principled law-breaking, activists call attention to a particular law or policy and demonstrate that in their considered opinion it is unjust and ought to be reversed. ${ }^{1}$ On this view, civil disobedience is a form of speech addressed to a political majority of voters or law-makers who are convinced to change course not by being cajoled but through the moral persuasiveness of the activists' cause and the strength and sincerity of their conviction.

In the words of John Rawls's classic account, civil disobedience functions by appealing to the 'sense of justice' of fellow citizens and political officials and 'while it may warn and admonish, it is not itself a threat'. ${ }^{2}$ Jürgen Habermas likewise emphasised the 'exclusively symbolic character of an act of protest, even when that act oversteps the bounds of the legally permissible', arguing that civil disobedience appeals to the 'capacity for reason and sense of justice of the majority'. ${ }^{3}$ For Peter Singer, too, disobedience is 'not an attempt to coerce', but instead functions to publicise an issue and ask the democratic majority to reconsider it in a special way by demonstrating the strength of feeling behind it. ${ }^{4}$ For these liberal philosophers, coercive tactics pose above all a counter-majoritarian problem - they are an illegitimate attack on the principle of political equality which requires that the verdict of a majority of citizens as expressed in free and fair elections should be treated as sovereign. The use of coercion by political movements risks replacing the verdict of a majority with that of a loud and assertive minority. In addition to this worry, coercive tactics are thought to undermine the deliberative ideal of politics as a collective undertaking animated by reason and underpinned by norms of mutual respect between citizens. The adherence to exclusively symbolic forms of protest is taken as a sign of respect for the rule of law and the idea of a democratic constitutional order, distinguishing civil disobedience from revolutionary measures aimed at the overthrow of the state.

In recent debates, more permissive theories of disobedience have been proposed by the likes of Daniel Markovits, Kimberley Brownlee and William Smith which see a role for political law-breaking as a 
response to the defects of the democratic process, rather than the traditional liberal focus on the protection of civil rights. ${ }^{5}$ These theorists argue that constrained forms of coercion may be justified as a means to bring marginalised perspectives into the public sphere. However, they specify that any use of coercive methods should avoid attempting to influence the outcome of political decisions by attempting to obstruct and reverse measures directly. The position of these theorists is therefore consistent with the traditional liberal conception of disobedience as fundamentally a communicative address, rather than involving the direct exercise of power.

This liberal reading of disobedience is rejected by radicals for being overly naive and optimistic given the political constraints movements face in advancing their cause in situations of inequality and injustice. Theorists of radical democracy, such as Robin Celikates and John Medearis, present disobedience as a confrontational practice that requires the use of concerted pressure against powerful opponents. ${ }^{6}$ However, while radicals are surely right to caution against the limits of reasoned persuasion alone as a force for change, this still leaves a number of important questions unresolved. Specifically, how can the use of compulsion be reconciled with the persuasive dimension of disobedience and with a more general commitment to democratic norms? What forms of cost is it permissible to impose in pursuit of one's goals and upon whom? What responsibilities, if any, do political agents have in using coercive tactics? In their defence of antagonistic modes of engagement, theorists of radical democracy sometimes obscure what is at stake in the choice between different tactics.

In this paper, I offer a principled theoretical defence of coercive forms of disobedience, not only in repressive states but in democratic and semi-democratic societies with established electoral and constitutional channels for pursuing change. ${ }^{7}$ I argue that coercion - which involves imposing costs on some political course of action or making it impossible to pursue by force - can be justified on democratic republican grounds as a means to collectively contest certain objectionable forms of 
political domination. Specifically, it is a justified response to forms of political domination that are intense (with damaging effects on the life chances of some group or future group of persons) and entrenched (distorting the conditions under which appeals to reason are effective). I contend that liberal and deliberative theories of disobedience have downplayed the role of social power and material interests in shaping political outcomes. They have construed injustice as the product of majoritarian error or moral oversight, leading them to assume that existing channels can be relied upon to bring about change through collective democratic reasoning once the injustice of the status quo is brought to public attention. Yet where political inequalities are pervasive, activists face formidable institutional and strategic obstacles to advancing their cause and the constitutional settlement itself may be a source of injustice. It may, for instance, systematically disadvantage some social group in its very definition of citizenship or indirectly support the monopolisation of power by the wealthy. A republican perspective of non-domination offers a valuable corrective since it calls attention to the pervasive threat of arbitrary power and its insidious mode of operation independent of any overt actions by the powerful. It brings into focus the relative capacity for strategic selfassertion possessed by individuals and groups within the state, responding to the practical need to arrive at collective decisions in ways that prevent a single group, class or individual from becoming political master.

In Section 1 of the paper, I define what I mean by persuasion and coercion. In order to elucidate the mechanisms of influence at the disposal of political movements, I focus first on coercion which takes place between two agents. As we shall see, however, it is also meaningful to talk of the coercive effects of social institutions and structures, which is relevant when it comes to examining the relations of domination that movements must confront. In Section 2 I set out an account of democratic legitimacy based on the republican - or 'neo-republican' - ideal of democracy as freedom from the threat of dominating power, while pointing out the shortcomings of mainstream republican theories in the face of contemporary forms of domination. In Section 3 I distinguish my argument from recent 
normative theories of disobedience as democracy-promoting. In Section 4 I discuss the use of coercion as a surrogate tool of political action for those who lack effective participation rights and in Section 5 I discuss coercion as a remedial tool to counteract the dominating influence of powerful actors over the process of democratic will formation. In Section 6 I examine the use of coercion as a mobilisational tool to maintain participation and discipline in collective action. I conclude in Section 7 by proposing regulative norms for the use of coercive tactics, which are designed to offset the potential that movements themselves become a source of arbitrary power by modelling democratic practices and ideals.

\section{Coercion, persuasion and power}

Persuasion and coercion can both be understood as techniques by which one agent attempts to influence the behaviour of another. The use of persuasion involves offering reasons and arguments in support of a particular course of action, which the addressee is asked to voluntarily endorse. Persuasion typically involves written or oral communication, such as speeches, chants, posters, blogs or newspaper columns. Action itself can be persuasive even in the absence of verbal content, however, where the communicative context makes it clear what is being said, as when an audience's refusal to clap during a politician's speech is taken as a sign of disagreement and condemnation.

When I refer to coercion between agents, I shall mean any interference by an agent, A, in the choices of another agent, B, with the aim of compelling B to behave in a way that they would not otherwise do. ${ }^{8}$ This interference can take the form of deterrent, forceful or deceitful coercion, each of which negatively affects the choice situation of the target agent who is being coerced. ${ }^{9}$ Deterrence influences an agent's cost-benefit calculations by imposing sanctions on an option, as when A tells B to leave their property or pay a fine. In order to qualify as deterrent coercion, the threatened sanction must affect the interests of the target in a way that is significant without necessarily being irresistible. 
Actions that are merely irritating to the target without significantly affecting their interests do not count as coercive. If A's proposed consequence for B not leaving the property is that A will sing in an irritating voice, then that does not plausibly count as coercive.

Forceful coercion compels the target agent to abandon a course of action through physical means by removing it entirely from their set of options, as when A physically drags B off their property. An important distinction lies in the fact that while forceful coercion functions by bypassing the will of the target, deterrent coercion achieves its aims through the active choices of the target who always has the option to accept the sanction and so deprive the coercer of their aims. B, for example, may choose to suffer the cost of the threatened fine to stay on A's property. ${ }^{10}$ In this way, deterrence produces an alteration in the incentives of the target without fully usurping their autonomy and removing their ability to choose. Deceit involves deliberately misleading another, so that they act in a way they would not have otherwise chosen, as when A lies to B that the property is on fire to get B to leave. ${ }^{11}$ This conceptual overview provides us with three different modalities through which coercion attacks the autonomy of its target: deterrence alters the options available to the target; force prevents them from choosing between options and deceit subverts the grounds on which their choice is made.

Where does violence fit into this picture? Violence involves the use of physical force to injure, kill or overwhelm other persons or else to attack property in a way that threatens persons with harm. ${ }^{12}$ Violence can be used both as a way of forcing another agent to do something (A drags B off the property) or as a way of deterring them from not doing it (A threatens to smack B if he does not leave). Violence is especially potent as a means of coercion because it directly implicates the most fundamental interest human beings have in bodily integrity and functioning. Yet not all violence is coercive. Violence may be carried out for any number of reasons and, where suitably constrained, it may even be used in an attempt to capture attention and communicate the intensity of one's demands. 
I shall return to the distinctive normative issues raised by the use of violence in Section 7, noting for now how it cuts across the distinctions I have given.

In practice, many forms of protest will combine elements which, on the face of it, seem to be both coercive and persuasive. Even the most peaceful march, for example, imposes some costs on others in terms of the noise, the closure of roads, the economic resources for policing and so on. It also carries with it some element of threat, too, given the potential for social disorder when large numbers of people gather together to air grievances. Arguably, whenever political action extends to breaking the law, no matter how emphatic the symbolic component of the action, it implicitly communicates a message of defiance to the authorities with the prospect of further instability should they not change course. On the other hand, even a violent riot will typically be accompanied by persuasive content that justifies the action, perhaps in the form of chants or graffiti.

When it comes to the terrain of real-world action, there is a certain degree of indeterminacy involved. Yet it does not follow that no principled distinctions can be drawn. With respect to coercion, it is plausible to suggest that there is a certain threshold point where an action 'crosses the line' into becoming coercive. If a protest blocks a road for an hour, it is an inconvenience; but if it does so for a week, then that reasonably counts as coercive. A coercive action can be distinguished from the merely symbolic where it credibly makes it more difficult for the state to carry through its intentions, requiring it to re-direct resources to the problem and undercutting its capacity to maintain the orderly functioning of social and economic institutions. As will become clear, keeping these distinctions in focus is important because each method of influence involves a specific way of treating and relating to opponents that warrants normative attention. While coercion is not necessarily wrongful, agents are prone to abusing it in order to get their way.

\section{Democracy and counter-power}


When an agent uses coercion, they exercise a form of power. Yet power involves the capacity to coercively interfere in the choices of another agent without necessarily having to exercise that capacity. This is significant when it comes to appreciating the power structures political movements must confront, which extend beyond discrete acts of coercive interference to regularised system of rules and norms that shape and constrains the choices of those subject to them through their coercive effects. ${ }^{13}$ In contemporary political theory, this insight has been developed systematically by thinkers in the republican tradition. For republicans, coercive power is a perennial feature of political life. Yet while its existence merits attention, coercion is not bad per se since it is capable of being disciplined and directed to worthwhile ends. The value of democracy, for republicans, lies in its role in safeguarding individual and collective freedom by controlling relations of power that would otherwise give rise to domination.

What, then, does it mean for power to be dominating? In the influential analysis of Philip Pettit, domination exists whenever some agent enjoys the power to coercively interfere in the choices of another on an arbitrary basis. Interference counts as arbitrary if it is the product of an 'alien' will over which the subordinate agent has little or no control. ${ }^{14}$ A dominating agent is able to issue orders and impose their will with impunity, knowing that they will not have to account for their actions or face any consequences. In such a condition, the subordinate party is dominated and hence unfree. Importantly, republicans point out that a dominating agent may never need to exercise their power for its effects to be felt. Where an agent enjoys the capacity for coercive interference and their desires and interests are a matter of common knowledge, others may come to regulate their behaviour accordingly to curry favour and prevent any possible repercussions. ${ }^{15}$ To be free, then, an agent must be suitably empowered to exert influence over the making of the decisions they are subject to and oppose the outcome of those decisions where necessary. 
A key point of difference between republicans and liberals concerns the conditions under which coercion counts as a limitation on freedom. Liberals have tended to regard any coercive interference by one agent in the choices of another as a restriction on freedom. ${ }^{16}$ For republicans, by contrast, the mere presence of coercive power is not objectionable so long as it is subject to a suitable degree of control. The law coercively interferes in our choices on a regular basis but what matters from the point of view of freedom as non-domination is whether this is done in an arbitrary way without regard for democratic procedures. A regime is democratic to the extent that it minimises domination by ensuring that the will of government - and hence the coercive enforcement of law - is controlled by those subject to it. In order to be free, those subject to political authority, the 'people' - which includes all adults who are more or less permanent residents of the state - must be empowered to shape and contest the law to ensure it tracks their ideas and interests. ${ }^{17}$

In their proposals for how freedom as non-domination is to be secured, contemporary republican thinkers have tended to emphasise the formal rights of citizenship exercised within the framework of the democratic constitutional state. The election of representatives to majoritarian legislatures is understood as a means to shape the law by imposing a directive influence over government decisions, while courts and other institutional forums are understood to provide opportunities to challenge and amend the law to ensure it is non-dominating. By contrast, there has been less attention to the role of popular action as a means to counteract the threat of dominating power undisciplined by the checks and balances of formal constitutional procedures. ${ }^{18}$ In Pettit's model of a republican state, the activities of social movements are valued in light of their role in defining social norms and campaigning for their adoption in a vibrant, pluralistic public sphere. ${ }^{19}$ In his most recent statement of republican theory, Pettit talks frequently of 'resistance', but this is considered less as an ongoing material practice, than as an idea - a 'possibility' - that encourages the appropriate degree of responsiveness from a legitimate regime. ${ }^{20}$ Even civil disobedience is a form of opposition that takes place 'within the system' with the aim of communicating reasons and enhancing the quality of public 
deliberation. ${ }^{21}$ This narrow focus on state institutions and the promotion of deliberation misses how popular power can be a means of collectively contesting relations of domination directly in circumstances where the political process is deficient.

When is coercive disobedience of this kind justified? There are good reasons to think that the mere presence of arbitrary power does not generate a demand for more confrontational measures so long as it is kept within certain bounds. In modern representative systems there will regularly be cases where political officials enjoy arbitrary power within some domain of decision-making. This follows from certain predictable pathologies of electoral politics and the unavoidable indeterminacy involved in the interpretation and application of law. To justify resistance, it must instead be an intensive form of domination in which arbitrary power is being abused in ways that affect the basic interests and life chances of some group or future group of persons. It is not possible to second guess in advance the precise range of issues which may demand such a response, but the key idea is the abuse of unchecked power to commit serious harms. This may involve the violation of individual or group rights, or else decisions over war and peace, over the fate of the environment or some other matter of social importance.

There is good reason to think that the use of coercion should also be reserved for circumstances in which political domination is entrenched, by which I mean that relations of power systematically distort the conditions under which reason can be relied upon to bring about change. This is likely to be the case where there are pervasive inequalities in access to political rights or where some private agent or group of agents has ongoing leverage over the institutions of collective will formation. These inequalities are often maintained and reproduced at the structural level, as Marxists, feminists and other critical theorists of power have pointed out. Political domination is entrenched where economic and political elites enjoy control over the production and transmission of information in society through direct and indirect control of society's major media, educational and cultural institutions and 
the role these play in the reproduction of dominant values, habits and identities. Over time, such processes operate in the interests of society's privileged social groups and classes without the need for any conscious or intentional exercise of power on their part.

Political domination is also compounded by exclusionary and discriminatory structures of norms in society which systematically marginalise or devalue the contribution of some groups to democratic decision-making. Typically, disadvantage attaches itself to class, gender, race, ethnicity, nationality, religion, sexual status, immigrant status, language or disability. It may result from unequal access to political capital that comes with education and access to privileged social networks and it is frequently perpetuated at the level of unconscious thought and behaviour, making it difficult to overcome. ${ }^{22}$ Where domination is entrenched, there may be little prospect of achieving reform through ordinary political and constitutional measures or through reasoned efforts in the public sphere. The powerful may simply be unwilling to deliberate or else they may have become habitually desensitised to the just demands of subordinate groups.

In practice, the criteria for what counts as objectionable domination will invariably be subject to multiple conflicting interpretations given deep-seated ideological disagreements within society. One response to this uncertainty might be to restrict the permissible grounds of resistance to a narrow set of pre-defined substantive issues, such as the protection of human rights, or to procedural concerns for which there are clear public standards, such as the electoral disenfranchisement of a minority group. However, this approach risks foreclosing the democratic process in advance, overlooking unanticipated abuses of power that have yet to be publicly articulated. Objectionable power relations may be entrenched in the prevailing norms of political and constitutional legitimacy in ways that even the beneficiaries of the status quo are not aware of. Movements have a democratic role to play in contesting these norms as possible sources of domination by defining and authoring new claims and new standards of justification. Even basic liberal notions - such as private property rights - may be 
called into question by this process. There is no objective standard for what counts as objectionable domination that can be appealed to external to the political process itself. It is important, therefore, that movements do not seek to deny or evade the contestability of the political judgements that inform their actions, but embody so far as possible certain democratic ideals in their conduct even while employing aggressive methods. I return to this issue in Section 7.

\section{Recent democratic theories of disobedience}

In recent debates, there has been some acknowledgment of the role that more confrontational protest tactics can play in remedying the defects of the democratic process by forcing engagement and compelling recalcitrant power-holders into democratic dialogue and deliberation. As Kimberley Brownlee writes, disobedients may sometimes need to employ limited pressure tactics to get their issue 'onto the table'. A certain amount of constrained coercion, for Brownlee, is a means to gain the attention of power-holders who are disinclined to engage in 'moral dialogue' understood as a forwardlooking moral discussion characterised by reciprocity and mutual respect. However, any protest of this kind should not aim to bypass reason-giving processes that aim to convert others. Too 'radical' a form of intervention, notes Brownlee, risks undermining the moral basis of one's appeal. ${ }^{23}$

In the 'deliberative' account of William Smith, civil disobedience can be a tool to publicise marginalised discourses and compel the powerful to submit their interests and preferences to democratic scrutiny. Smith proposes that the use of 'limited coercion' may be necessary as a means to gain publicity for one's cause. However, it should not 'escalate into an attempt to impose a settlement through illegitimate force'. Any attempt to coerce the will of the state itself, notes Smith, would be 'difficult to reconcile with the duty to respect the entitlement of free and equal citizens to collectively determine law and policy through democratic procedures'. ${ }^{24}$ Daniel Markovits, meanwhile, argues that political law-breaking may be a legitimate response to certain predictable 
pathologies of the formal political process that result in deliberative 'inertia'. ${ }^{25}$ For Markovits, some degree of coercion may be required in order to bring about engagement, though he stresses that the ultimate aim of such actions is to promote collective reconsideration of the issue in question. As he puts it, disobedience may coerce the 'fact' of re-engagement, but not the outcome itself. ${ }^{26}$

Whereas the classical liberal account of disobedience was informed by minority struggles for civil rights, these theories see a role for unlawful political conduct in response to fundamental inequalities of power and the systematic bias of the public sphere. In this way, they bring into focus the dimension of power as agenda-setting. The accounts of Brownlee, Smith and Markovits acknowledge that even in broadly democratic systems there will be occasions when public debate is unfavourable to certain specific viewpoints or where political institutions are unresponsive. Here, political law-breaking that is purely symbolic and nonintrusive may not be enough to attract public attention and some constrained measures of coercion may be required to compel an issue into discussion.

The problem is that these accounts retain an overly optimistic view of the democratic credentials of existing states and in the power of moral dialogue and deliberation alone to correct injustice. The hope is that contentious issues can be resolved through an appeal to reasoned argument and the achievement of some degree of public consensus. The core issue these theories confront is the ignorance of voters and public officials, rather than powerful institutions, social groups and classes aggressively pursuing their self-interest without regard for the common good. The state thus figures less as an independent source of domination, vulnerable to corruption and capture, than as a neutral framework within which deliberation among citizens takes place. The outcome of such deliberations is then assumed to be translated into law and policy in a broadly accurate and reliable manner via elections and majority votes in the legislature. Under this picture, any use of coercion by social movements comes to be seen as a deviation from a broadly coercion-free deliberative baseline of decision-making and a straight-forward attempt to obstruct the will of a political majority. 
It follows from thinking of coercive tactics in exclusively instrumental terms as a way of promoting engagement and enhancing public debate, that the justification for them ceases once a degree of attention has been secured. Accordingly, for Smith, once a marginalised discourse has been brought to the centre of public debate, it is best for protesters take a step back to allow the ordinary process of opinion-formation to take place. ${ }^{27}$ Markovits goes so far as to suggest that movements might proceed with disobedience without any positive agenda for changing policy, since the aim is solely to promote engagement. ${ }^{28}$ Where structures of domination systematically bias the public sphere, however, the fact a marginalised issue has been put on the agenda of political discussion does not suffice to ensure it will be fairly assessed. If those in authority do agree to engage in discussion, this does not entail a rupture with the unequal power relationships of the past, which would be a prerequisite for a reciprocal dialogue to take place.

Political inequalities will continue to structure the terrain of decision-making even after some measure of publicity has been achieved. This helps explain why many protest movements do not simply call a halt to their activities once they have attracted publicity to their cause, but instead frequently continue and even escalate their campaigns of disobedience. Consider the issue of climate change. The argument for cutting fossil fuel emissions to contain the prospect of ecological catastrophe was 'won' in the public sphere a long time ago. However, the necessary changes in government policy have still not taken place, which is in large part due to the controlling influence that the extractive industries still enjoy over the policy-making process in the US and elsewhere. In this context, there is a clear argument for escalating disobedient actions beyond symbolic protests aimed at garnering publicity, to forms of sustained coercive pressure.

An alternative, radical democratic account is provided by John Medearis who proposes to reject the persuasion-coercion binary entirely as a part of a broader critique of ideal approaches to theorising 
democracy. Medearis argues that oppositional action by social movements is central to democratic life, even when these movements embrace confrontational or otherwise non-deliberative methods. His approach shares with republicanism the view that coercion is pervasive in politics and that democracy has a certain reactive character as an ongoing effort to manage the encroachments of shared institutions and structures through countervailing sources of power. In contrast with Pettit's republicanism, however, Medearis places a welcome emphasis on how power resources may be leveraged not only by citizens acting through the intermediary of public institutions, but through the roles people occupy within social relationships of various sorts as workers, students, renters, taxpayers, borrowers, consumers, and so on, given the opportunities such positions afford for strategic noncooperation and disruption. For Medearis, democracy involves continual exertion against the ineradicable reality of alienating structures, with no expectation of 'transcendent victory' in the achievement of a deliberative ideal. ${ }^{29}$ By chipping away at accepted distinctions, and showing how deeply embedded power relations are in the ordinary conduct of politics, Medearis hopes to vindicate the more conflictual elements of movement practice.

A great strength of Medearis's account is to broaden the scope of democratic theorising beyond the tightly-regulated institutional focus of much of the deliberative literature and his argument for the value of coercive protest in challenging power relations is compelling. At points, however, his analysis blurs the conceptual boundaries between coercive and persuasive forms of engagement with a diverse range of movement tactics grouped together under the label of democratic 'oppositional' practice. Medearis's broad contention is that coercive power is so prevalent in political life that no special justification is required for movements to avail themselves of it. If we accept the logic of this position, however, it is difficult to see how progressive movements of the kind Medearis favours could reserve this right for themselves and deny it to others. Were activists to deny that there was any principled distinction to be made between attempting to convince others of their demands or attempting to unilaterally impose them, then they could not then coherently object to corporations, 
wealthy individuals and other strategically better-placed actors imposing their own interests and preferences through their own power. They would therefore lack a clear and consistent basis to identify and condemn the political inequalities they oppose. In practice, movements tend to acknowledge a presumption in favour of persuasive means where possible, even where the inequities of the status quo mandate more robust alternatives. The use of confrontational measures is then justified on the basis of a specific democratic procedural claim in relation to the issue at hand with occupations, strikes and other such tactics presented as the only viable option where institutional channels are unresponsive or unavailable.

Medearis directs some important criticisms at the idea of a future 'pure' or 'utopian' deliberative democratic society purged of coercion. At points, however, he appears to reject democratic ideals as such based on misguided assumptions about what endorsing an ideal entails. ${ }^{30}$ Contrary to some of Medearis's criticisms, commitment to a democratic ideal - such as non-domination - does not presuppose that such an ideal is instantiated in the normal course of affairs or even that it is going to be achieved sometime in the future. It follows that political action guided by an ideal need not be undertaken to establish (or re-establish) that ideal. It may instead be undertaken to oppose departures from the ideal insofar as possible. At points, Medearis assumes the orienting function of democratic ideals when he notes that movements take action against 'alienating' structures (in particular) and do so 'in a way that strives for equality of power'. ${ }^{31}$ Yet equal power is a demanding democratic ideal, which is certainly remote from existing practices. Its invocation by Medearis also sits in tension with his claim that democracy itself is a form of ceaseless oppositional struggle since movements would then be striving for something they already instantiate. This suggests that the oppositional activity of social movements is valued not for its own sake, but in light of the specific democratic ideals it aims at. In the next part of this paper, I consider more specifically when robust measures are justified.

\section{Coercion as a surrogate tool}


The use of coercive disobedience is justified as a surrogate tool of political action in response to the state's intensive domination of part of the people subject to its rule. This is the case for groups who are vulnerable to the state's coercive power and yet who lack equal access to a political say in determining how that power is exercised. The political relations of domination justifying the use of such means take the form of both formal and informal obstacles to participation. ${ }^{32}$ Formal obstacles to participation refer to laws and regulations that deny equal access to democratic fora. While historically, workers, women and racial minorities are among those groups who have been politically disenfranchised, today those facing legal obstacles to political participation include undocumented migrants and refugees, and prisoners and the homeless in a number of jurisdictions. It may also include minorities whose participation is deliberately suppressed by voter ID laws, redistricting and other measures. Informal obstacles to participation are experienced by those whose identity is stigmatised in public debate and who lack the education and basic material resources to participate on equal terms with others. Although those confronted with informal obstacles to participation are not legally excluded, they suffer from various forms of disadvantage and stigma which entail that their contribution is devalued in political debate.

Importantly, the situation of excluded minorities of this kind is normatively distinct from that of a minority which loses out to the majority in a democratic decision, and not just because of the content of the loss. A defeated minority whose interests have been over-ridden by a democratic decision will nonetheless have some ownership of that decision if they had past opportunities for influence and have some future hope of being on the winning side. By contrast, excluded minorities have little prospect of reversing the decisions they are subject to through voting, legal channels or public deliberation. Traditionally, the courts are thought to provide a forum in which vulnerable minorities can vindicate their claims through appeal to protected legal rights. However, the law is incapable of anticipating in advance the precise form and character that every instance of domination will take. ${ }^{33}$ 
Moreover, while judges may be to some degree insulated from majoritarian passions, they are not immune to the social biases and privilege of powerful groups. Frequently, the state itself has had a troubling history of oppression in relation to dominated groups and cannot be expected to handle their claims in a neutral and impartial manner. Where part of the people is subject to intense, entrenched domination communicative forms of civil disobedience may be of limited effectiveness or may simply be too impractical and costly to carry out.

Consider the case of undocumented migrants who lack legal citizenship rights. As a group, they are intensely vulnerable to abuse, exploitation and repression and yet they lack the formal citizenship rights to advance their interests possessed by legal members of the state or the secure public standing to make claims enjoyed by legally resident non-citizens. As Luis Cabrera has noted, it is possible that the transgression of immigration controls may be carried out as a form of 'global civil disobedience' that broadcasts the injustices migrants experience. ${ }^{34}$ However, it remains the case that a public breach of law as part of a political protest risks exposing them to arrest, detention and deportation. Even where irregular migrants have access to institutional avenues to make their case in public debate, they confront pervasive forms of discrimination encouraged by a media that promotes intolerance and misinformation. In these circumstances, there is an argument for assertive measures by migrant activists and their allies to frustrate the immigration enforcement system and make it unworkable. Thus, migrant solidarity movements physically obstruct immigration raids, resist deportation flights, sabotage border fences, conduct occupations of public buildings, or else attempt to overwhelm the institutional viability of immigration enforcement. In so doing, they collectively contest a harsh and restrictive immigration regime by raising the costs of its enforcement.

More radial forms of protest are also a means to contest informal exclusion. A historically oppressed racial minority may possess formal voting rights and yet continue to be subject to coercive and unaccountable state intrusion in the form of a racist system of policing and criminal justice. When 
members of this group attempt to raise their grievances about this pervasive mistreatment in the media and public forums, their concerns are systematically marginalised relative to those of the social majority. They may for instance be subjected to racist stereotypes that frame them as predisposed to aggression and criminality. The power structure represented by such a system of racist policing and criminal justice is a case of objectionable domination because it threatens fundamental interests without being readily amenable to modification in light of the formal participation of those subject to it. In light of this, the disruptive tactics of the kind deployed by the 'Black Lives Matter' movement in the US are intelligible as a form of democratic counter-power for those denied effective participation rights.

\section{Coercion as a remedial tool}

The use of coercive disobedience may also be legitimate as a remedial tool of political action when the state dominates the people as a whole due to the corrupting influence of private wills on the process of collective will-formation. In many existing liberal states, powerful private agents are able to use their influence over the policy-making process to advance their preferences and interests with inadequate legal and constitutional constraints on their power. ${ }^{35}$ Although these private agents do not themselves necessarily have control of the coercive machinery of the state, they intervene in its decisions to further their own interests. This is especially troubling in those states, such as the UK and US, with sharp social and economic inequalities and limited regulation of monied influence on parties and politicians. Corporations, wealthy donors, lobbyists, media owners, policy agencies and trans-national institutions frequently wield an opaque and unaccountable power over political decisions through their behind-the-scenes input into policy-making and their domination of public discourse.

Importantly, the power of these private agents need not be exercised for its effects to be felt. It will 
still count as domination when politicians shape their behaviour in the desired direction in anticipation of the reaction of powerful groups and classes. Over time, the combined effect of this influence is to restrict the political choices available to citizens so that decision-making takes place within a narrow spectrum of debate favourable to the interests and preferences of the powerful. Some important areas of policy-making are not put to voters at all and therefore escape democratic scrutiny altogether. However, even a policy ostensibly endorsed by a majority of voters at election time may have only succeeded thanks to the exclusion and penalising of alternative possibilities. The major political parties, for instance, may be afraid to oppose the deregulation of the labour market out of fear that corporations will donate to their political rivals or else carry through on their threats to move their operations abroad at the cost of jobs and tax revenues. These parties then tell voters that the labour market needs reform. The electorate duly votes for one of these parties, in the absence of an alternative, and the policy of labor market deregulation has seemingly been endorsed by a democratic majority. ${ }^{36}$

Where the influence of private agents distorts the political process in this way, the use of remedial coercion by political movements may function as a countervailing force that reduces the ability of the powerful to impose their will unchecked. These forms of remedial coercion are often targeted directly at the perpetrators of some perceived wrong, rather than appealing to the government or a third party of the reasoning public for support. The purpose here is to compel private actors to stop the wrongful behaviour they are engaged in or else to pressure them to drop their political opposition to the desired legal or policy reforms. A recent example is provided by environmental activists occupying sacred lands to prevent the drilling of oil-pipelines in North Dakota and elsewhere. ${ }^{37}$ Notoriously, the extractive industry in the US enjoys significant leverage over the policy-making process thanks to campaign finance, lobbying and a system of revolving doors between business and politics. According to the former presidential candidate turned climate change advocate Al Gore, it is almost impossible to enact political reform 'without first seeking and gaining permission from the largest 
commercial interests who are most affected by the proposed change'. ${ }^{38}$ The democratic rationale for occupations, sabotage and other forms of confrontational environmental activism in this context is to directly counteract the dominating influence of the extractive industry over collective decisions. Here, disobedience helps to rebalance the playing field, modifying the objectionable effects of power on the formation of policy.

\section{Coercion as a mobilisational tool}

The success of any campaign of collective action typically depends upon widespread, disciplined participation. High levels of participation enhance the democratic credentials of a campaign by broadcasting the popular support it enjoys. But participation is also crucial to the coercive strength of a movement where its strategy involves the imposition of costs upon adversaries. The success of illegal strikes, occupations, disruptive protests, and mass civil disobedience campaigns crucially depends on the mobilisation of a critical mass of participants. What means are available to activists, then, to maintain and build participation in collective action? The individualistic framework of most philosophical accounts of disobedience lead them to neglect this question. Theorists have proposed arguments for the existence of an individual moral right to disobey the law, ${ }^{39}$ while others have argued for a duty to disobey in response to injustice. ${ }^{40}$ They have said little however about what can be done when an individual fails to exercise their rights in situations where they ought to or when an individual fails to act upon their duties of justice. ${ }^{41}$

There are important structural vulnerabilities to campaigns of collective action which entail that the non-participation of some members of a group compromises the overall effectiveness of an action. An illegal strike which is ignored by some section of workers, for example, will be a far weaker deterrent to managers and government than one which shuts down the workplace entirely with the resultant disruption and drop in production. As a result, the short-time and self-regarding behaviour 
of the few risks undermining the long-term interests of the collective. In addition, individuals who are committed to the aims of a campaign or positioned to benefit from its success may weigh the potential costs and gains of their participation in the knowledge that their involvement alone has only a marginal possibility of influencing the overall outcome. The most rational course of action in these circumstances may be to free-ride off the participation of others, enjoying the benefits gained if the campaign succeeds without risking any of the potential costs of participation. ${ }^{42}$

An exclusive reliance on moral motivation then may be insufficient to ensure people 'do their part' and there may then be an argument for various forms of coercive pressure against individuals. ${ }^{43} \mathrm{~A}$ liberal perspective is typically hostile to the use of private coercion to enforce participation in collective action, which conflicts with individual rights of freedom and association. A liberal perspective instead requires that exclusively voluntary forms of persuasive influence should be used to mobilise people in accord with the moral autonomy of individuals. In the US, the UK and other liberal capitalist economies, a body of labour law has been developed to enforce this voluntarist approach and prevent violence and coercion on picket lines. While lawful striking workers are now less susceptible to violence at the hands of the police, such restrictions may also blunt the effectiveness of industrial action in certain cases. The problem is that the non-exercise of rights to political action by some individuals threatens to render the rights of others ineffective. Rights to political participation are to a large extent collective rights that must be exercised by a sufficiently large section of a collective to be meaningfully enjoyed by anyone. ${ }^{44}$ This is recognised in some contemporary liberal societies in the form of a mandatory legal right to vote at elections. The rationale for having a mandatory right to vote follows from the value of democracy not merely as a means of aggregating individual preferences, but as a device that serves the common goal of informed and accountable public decision-making. Democracy is a good that is collectively produced through a sufficiently large number of people exercising their rights of participation. 
By analogy, if there are rights to political participation outside the state - including rights to disobey the law and to engage in collective action - there is an argument for some degree of coercive enforcement of those rights. Naturally, the state - whose very actions and authority is at issue - cannot be relied upon to carry out this role and therefore it falls to suitably positioned private agents. It is difficult to say too much about the kinds of penalties that are appropriate to support mobilisation beyond the specific context involved, but they may include co-ordinated social denunciation and exclusion. The use of physical force may also be justified within certain limits. For example, an illegal strike or workplace occupation is enforced by striking workers who use their bodies and other barriers to obstruct entry into the workplace or engage in moderate forms of violence. The use of coercion may also be required to uphold agreed standards of conduct and prevent reckless behaviour and sabotage that imperil the success of collective action. In the next section, I consider more closely what forms of action are permitted.

\section{Norms for the use of coercive tactics}

As I have touched upon, many of the constraints that have traditionally been proposed on the conduct of liberal disobedience - such as the requirement that it be done in public and that disobedient actors should accept any legal punishment for their actions - are too burdensome to be adhered to in every context and in many cases would risk jeopardising the effectiveness of collective action. Importantly, disobedience in the real world often takes place within a context of intrusive state surveillance and data gathering, violent and discriminatory forms of policing and disproportionate legal punishments and this context invariably affects how oppositional politics is conducted. There are nonetheless a number of plausible constraints on the use of more robust measures. These are understood not as categorical moral constraints on politics, but as principles which flow from an understanding of disobedience as a democratic practice for contesting relations of domination within the context of a shared political order. 
Recall that I am assuming the context of a plausibly democratic political order. This is one that frequently gives rise to domination but which nonetheless enjoys a certain degree of representative legitimacy and which has the capacity to secure important public goods. This points to two general principles of engagement from which more practical considerations can be derived. First, any action undertaken should be consistent with the political order itself remaining intact. The system is not totally devoid of legitimacy and the risks involved in overthrowing it or destabilising it to the point of collapse outweigh the goods it provides. Second, in undertaking political action, movements should not themselves become sources of private domination in relation to other citizens and residents of the state, including the wider constituency of interests they advocate for.

I consider first the question of violence. Robin Celikates has recently directed a number of powerful criticisms at Rawls and other prominent liberal theorists of civil disobedience who seemingly rule out any use of violence in liberal states by definitional fiat in light of their characterisation of disobedience as strictly symbolic. For Celikates, this serves to domesticate dissent, stripping it of its radical potential as a 'dynamizing counterweight to the rigidifying tendencies of state institutions' ${ }^{45}$ He urges a more careful consideration of which forms of political action count as violent, given a political and ideological context in which state authorities routinely criminalise even mild forms of disruption, such as blocking a street, as acts of violent intimidation. I am strongly sympathetic to the broad thrust of Celikates's critique. However, some of the argumentative strategies he employs risk running together different forms of political action in ways that obscure what is at stake. It is noted, for example, that there are forms of lawful, non-violent protest that may be more harmful in their practical effects than violence. ${ }^{46}$ A strike by ambulance workers, for example, will likely result in more suffering than many acts of violence. ${ }^{47}$ Nonviolent strategies, it is argued, also rely upon some degree of violence for their success since they frequently aim to invite violent suppression from the authorities in order to garner public sympathy and expose the repressive, violent character of the 
system being opposed. This leads Celikates to claim that "no inference should be made about the essential non-violence of this form of protest', which side-steps an important distinction between being the initiator of violence and being its recipient. ${ }^{48}$

Part of the difficulty stems from the fact that Celikates wishes to defend a radically inclusive conception of civil disobedience and so the constraints he envisages on political action are derived from a suitably broad interpretation of the notion of 'civility'. For Celikates, civility entails a political logic which requires that disobedient actors should acknowledge 'some kind of civil bond with their adversaries' while eschewing '[quasi-] military action aiming at the destruction of an enemy'. ${ }^{49}$ Other than this stipulation, however, there is little sense of any organic democratic constraints on the means available to activists or how such means interact with the nature and legitimacy of the political order being opposed. My objection here, however, is less with the substance of what Celikates's account permits than with the broad-brush characterisation of violent acts (short of insurrection and armed militancy) as 'civil', which would seem to obscure the qualitative difference between the various types of principled resistance.

A stance of political responsibility involves political agents taking ownership of the violence and harm that they themselves directly inflict and bring about through their actions. It is also important to consider how violence interacts with a group's aims and with wider democratic structures, given how its long-term consequences are notoriously difficult to calibrate and control. There are sound non-moralistic reasons behind the presumption against initiating violence in a broadly democratic society. Importantly, there is no straightforward translation from a realistic appraisal of the injustice of the status quo to the use of violent methods. This point is made persuasively by Karuna Mantena in her study of Gandhi's philosophy and practice. Mantena argues that Gandhi's nonviolence derived not from an absolutist adherence to moral principles, but from an appraisal of the dynamics of political conflict and escalation given a historically-informed understanding of human psychology and 
motivation. ${ }^{50}$ The use of violence seems most justified in cases of self-defence or to maintain the integrity and effectiveness of collective action. It may, for instance, be warranted for undocumented migrants to violently repel an immigration enforcement officer or for activists to forcefully defend an occupied space.

Where there are few alternatives, certain violent acts of property destruction may also serve to communicate outrage, indignation and a radical rejection of the status quo. The long-range effectiveness of such acts is open to question. ${ }^{51}$ However, there is a certain democratic logic to them insofar as they aim at broadcasting long-repressed grievances and do not seek to punish opponents or terrify them into submission. ${ }^{52}$ To a certain degree, provoking panic, fear and rage may be an unavoidable byproduct of certain forms of radical protest, but this should not be their goal. The emotional state of fear is inimical to the process of rational political decision-making and arguably, therefore, to democratic action itself. ${ }^{53}$ It follows, for example, that the 'liberation' of animals involved in medical experiments or even the vandalising of laboratory equipment by animal rights activists may be justified in a way that threatening letters and 'home visits' to the scientists involved in testing are not. ${ }^{54}$ The use of coercive disobedience should raise the cost of laws and policies deemed objectionable without using fear as a weapon to compel opponents into submission.

Plausibly, the use of coercion is easier to justify as a form of deterrence, than in forceful interventions that overwhelm government decision-making. While it may curtail the autonomy of government officials and voters, the imposition of coercive sanctions is still compatible with some measure of deliberation and so treats opponents as democratic interlocutors, responsive to reasons. By contrast, the successful usurpation of the government's will by force - as for example with a successful cyberattack that shuts down its operations on an ongoing basis - is more difficulty to justify outside of extreme cases. What can be said, then, of deceit? Can movements advance their cause by lying? In some cases, they may. We must consider however the target of any deception and its epistemic effects. 
It may, for instance, be permissible to undermine the institutional viability of a dominating immigration bureaucracy through various forms of administrative lying; by submitting false reports of illegal behaviour or else by using fake identity documents or 'sham marriages' to bypass enforcement.

The use of deceit in public debate is more troubling however since it more directly implicates the democratic autonomy of citizens. While movements may plausibly resort to certain forms of exaggerated rhetoric and hyperbole to cut through the inertial effects of public discourse, lying about the basic facts of law and policy seems less warranted. Within a broadly democratic society, there remains the expectation that where possible those engaged in radical acts of protest (or their allies) should give reasons and arguments in support of their aims; ones which are truthful to the best of their knowledge. This would ideally include a democratic procedural claim that identifies the objectionable relations of power that make such actions necessary.

Although the ultimate rationale for the action may not be to morally convince the government or one's fellow citizens, democratic norms require that there should be some effort to persuade others. It is reasonable to think however that this requirement is relaxed where it would attract unwanted attention to a vulnerable group, such as undocumented migrants. There is also good reason to think that those who undertake more assertive actions should enjoy a certain measure of representative legitimacy and accountability in relation to those whose rights and interests are most directly affected. It may not always be practical for a movement to have a formalised democratic structure, with actions agreed by majority vote, but the important thing is that there is a sufficient degree of responsiveness to the social groups most directly affected and that they have opportunities to influence the direction of any campaign. Not only does this confer moral authority, it also brings epistemic benefits. Political interventions that lack this degree of representative legitimacy risk leading to avoidable harms and generating new forms of domination over those whose interests the movement seeks to advance. ${ }^{55}$ 


\section{Conclusion}

The classic liberal philosophical notion of disobedience as a form of speech that functions by means of moral persuasion is partial and misleading. This approach operates with a set of idealising assumptions about the reliability of democratic processes, the conduct of politics and the scope of citizenship rights. Once we adopt this perspective, it becomes plausible to regard more radical forms of protest as an illegitimate deviation from a coercion-free baseline of democratic decision-making that is inconsistent with majority rule and mutual respect among citizens. The liberal model has always had difficulty in accounting for the specific nature of contentious politics and in explaining why moral argument should work when persuasion by constitutional means has been tried and failed. The republican approach I present, by contrast, recognises the necessity of some element of coercion given the pervasive reality of power inequalities, social divisions, ideological biases and material self-interest. I have argued that some measure of coercion is legitimate as a surrogate and remedial tool of political action in situations in which domination is intense and entrenched. In cases such as this, political actors mobilise power resources external to the formal democratic process to counteract the distorting effects of political domination. The deployment of popular power is not merely a prelude to dialogue, but a way of directly influencing the making of a decision, supplementing political arguments with other rational incentives. Insofar as possible, movements should strive to embody certain democratic norms of accountability and responsiveness in their behavior to avoid giving rise to objectionable forms of private domination. There is also a case for use of certain constrained forms of coercion as a mobilisational tool to ensure sustained and disciplined participation in collective action by stopping and penalising shirkers, free-riders and saboteurs. The aim of such actions is not merely to promote deliberation or to get the government to listen to one's demands, but to pressure them to yield. 


\footnotetext{
${ }^{1}$ John Rawls, A Theory of Justice, (Belknap Press, 1999); Jürgen Habermas, "Civil Disobedience: Litmus Test for the Democratic Constitutional State," Berkeley Journal of Sociology 30 (1985); Peter Singer, Democracy and Disobedience, vol. 82 (Cambridge University Press, 1973).

${ }^{2}$ Rawls, 1999, p. 322.

${ }^{3}$ Habermas, 1985, p. 99.

${ }^{4}$ Singer, 1973, p. 84.

${ }^{5}$ Markovits, Daniel. "Democratic disobedience." Yale LJ 114 (2004); Brownlee, Kimberley. Conscience and conviction: The case for civil disobedience. OUP Oxford, 2012; Smith, William. Civil disobedience and deliberative democracy. Routledge, 2013.

${ }^{6}$ Celikates, Robin. "Rethinking Civil Disobedience as a Practice of Contestation-Beyond the Liberal Paradigm." Constellations 23.1 (2016a): 37-45, at p. 43. Medearis, John. Why democracy is oppositional. Harvard University Press, (2015).

${ }^{7}$ The question of when coercive disobedience can be justified is distinct from the more general problem of the normative justification of civil disobedience. The central problematic that theories of civil disobedience have confronted is that of political obligation and the question of whether it is permitted to break the law for political reasons in violation of our purported duties of obedience. For the purposes of my argument, I assume that political law-breaking can be justified in order to focus specifically on the question of coercion. The central problematic here is not political obligation but the apparent transgression of democratic norms involved in the use of coercion by private agents.

${ }^{8}$ I assume that the state is a group agent with its own will that is implemented through law. In discussing the use of coercion in this section, it is the coercion of the state's will that I have in mind.

${ }^{9}$ My discussion here draws on Mansbridge, Jane, et al. "The place of self-interest and the role of power in deliberative democracy." Journal of Political Philosophy 18.1 (2010): 64-100.

${ }^{10}$ Some accounts of coercion focus exclusively on the issuing of threats by the coercer, implicating the will of the coercee. They therefore discount the use of physical force that obstructs a choice entirely, most influentially Robert Nozick, 'Coercion', Socratic puzzles. Harvard University Press, 1997. Yet while there are differences in how the two modes of influence operate, the reason for thinking that deterrence and force both count as coercion is that they fulfil an equivalent function in subordinating the target to the will of the coercer.

${ }^{11}$ On deceit as a form of coercion, see Warren, Mark E. "Democracy and deceit: regulating appearances of corruption." American Journal of Political Science 50.1 (2006), pp. 165-166.

${ }^{12}$ It follows that social context is key to determining whether any instance of property destruction counts as violence, including the proximity and vulnerability of other persons and the methods used. Methodically dismantling a tree-cutter with a set of tools, say, plausibly counts as non-violent in a way that blowing it up with explosives does not, even though the effects are comparable.

${ }^{13}$ For the notion of a 'coercive structure', see Scott A. Anderson, "Enforcement Approach to Coercion, The," J. Ethics \& Soc. Phil. 5 (2010).

${ }^{14}$ Pettit, Philip. On the people's terms: a republican theory and model of democracy. Cambridge University Press, 2012, p. 57.

${ }^{15}$ Pettit, 2012, pp. 66 - 67.

${ }^{16}$ Isaiah Berlin, 'Two Concepts of Liberty', in I. Berlin, Four Essays on Liberty, London: Oxford University Press. New ed. in Berlin 2002.

${ }^{17}$ Pettit 2012, pp. $239-292$.

${ }^{18}$ In one passage, Pettit nonetheless discusses the important advances of the trade union movement in expanding rights for workers, but then adds that there is 'little reason to be attracted to the strategy of reciprocal power as a general means of advancing people's freedom as non-domination', (2012), p. 95. Pettit's discussion here however presents the unmediated exercise of popular power as an alternative to constitutional politics rather than as a means of correcting for its defects, see Watkins, David.

"Institutionalizing Freedom as Non-domination: Democracy and the Role of the State." Polity 47.4 (2015): 508-534.

${ }^{19}$ Pettit, 2012, p. 226.

${ }^{20}$ Aitchison, Guy. "Three Models of Republican Rights: Juridical, Parliamentary and Populist." Political Studies, 65.2 (2017), pp. 7 - 8.

${ }^{21}$ Pettit 2012, p. 138.
} 
${ }^{22}$ See: Elizabeth S. Anderson, "What Is the Point of Equality?*," Ethics 109, no. 2 (1999): 287-337; Iris Marion Young, "Activist Challenges to Deliberative Democracy," Political Theory, 2001, 670-90.

${ }^{23}$ Brownlee, 2012, p. 18.

${ }^{24}$ Smith, 2013, p. 33.

${ }^{25}$ Markovits, 2005, p. 1921.

${ }^{26}$ Markovits, p. 1941.

${ }^{27}$ Smith 2013, p. 72.

${ }^{28}$ Markovits, 2005, p. 1941.

${ }^{29}$ Medearis, 2015, p. 2.

${ }^{30}$ Medearis, 2015, p. 22, p. 35, pp. 25-29.

${ }^{31}$ Medearis, 2015, p. 147.

${ }^{32}$ Iris Marion Young, Inclusion and Democracy (Oxford University Press, 2002), pp. 5 - 6. See also Elizabeth S. Anderson, "What Is the Point of Equality?*," Ethics 109, no. 2 (1999): 287-337.

${ }^{33}$ See Coffee, Alan MSJ. "Two spheres of domination: Republican theory, social norms and the insufficiency of negative freedom." Contemporary Political Theory 14.1 (2015): 45-62.

${ }^{34}$ Cabrera, Luis. The practice of global citizenship. Cambridge University Press, 2010.

${ }^{35}$ See Colin Crouch, Post-Democracy (Polity Cambridge, 2004); Jeffrey A. Winters, Oligarchy (Cambridge University Press, 2011); Gilens, Martin, and Benjamin I. Page. "Testing theories of American politics: Elites, interest groups, and average citizens." Perspectives on politics 12.3 (2014): 564-581; Stephen Wilks, The Political Power of the Business Corporation (Edward Elgar Publishing, 2013).

${ }^{36}$ Crouch, 2004, p. 33.

${ }^{37}$ Wong, Julia Carrie, 'Dakota Access pipeline: US denies key permit, a win for Standing Rock protesters', The Guardian, (2016), Available at: https:/www.theguardian.com/us-news/2016/dec/04/dakota-accesspipeline-permit-denied-standing-rock (accessed 19 December 2016). Environmental activists may also use acts of covert sabotage, such as tree-spiking, which are not plausibly about gaining publicity. See Welchman, Jennifer. "Is ecosabotage civil disobedience?." Philosophy \& Geography 4.1 (2001): 97-107.

${ }^{38}$ Quoted in Kevin Young and Michael Schwartz, "A Neglected Mechanism of Social Movement Political Influence: The Role of Anticorporate and Anti-Institutional Protest in Changing Government Policy," Mobilization: An International Quarterly 19, no. 3 (2014): 239-60, at p 244.

${ }^{39}$ Lefkowitz, David. "On a moral right to civil disobedience." Ethics 117.2 (2007): 202-233.

${ }^{40}$ Delmas, Candice. "Political resistance: A matter of fairness." Law and Philosophy 33.4 (2014): 465-488.

${ }^{41}$ An early exception is Michael Walzer's discussion of the sit-down strikes by workers in automobile factories in the US in the 1930's, Obligations: Essays on Disobedience, War and Citizenship (Harvard University Press, 1970), p. 5.

${ }^{42}$ Mancur Olson, The Logic of Collective Action, vol. 124 (Harvard University Press, 2009).

${ }^{43}$ On the role of social pressure in sustaining collective action, see Goodwin, Jeff, James M. Jasper, and Francesca Polletta, eds. Passionate politics: Emotions and social movements. University of Chicago Press, 2009.

${ }^{44}$ See the helpful discussion in Gourevitch, Alex. "Quitting work but not the job: Liberty and the right to strike." Perspectives on Politics 14.2 (2016): 307-323.

${ }^{45}$ Celikates, (2016a), 41.

${ }^{46}$ Celikates, (2016a), 41-42.

${ }^{47}$ This example comes from Joseph Raz, "Civil Disobedience," in The Authority of Law (Oxford: Clarendon Press, 1979), 262.

${ }^{48}$ Celikates, (2016a), 42.

${ }^{49}$ Celikates, Robin. "Democratizing civil disobedience." Philosophy \& Social Criticism, 42.10 (2016b), 986.

${ }^{50}$ Mantena, Karuna. "Another realism: the politics of Gandhian nonviolence." American Political Science Review 106.2 (2012): 455-470. See also Livingston, Alexander. "Between Means and Ends: Reconstructing Coercion in Dewey's Democratic Theory." American Political Science Review 111.3 (2017): 522-534.

${ }^{51}$ Wasow, Omar. "Do Protest tactics matter? Evidence from the 1960's black insurgency." Working paper, Princeton University, (2017). Available at: http://www.omarwasow.com/Protests_on_Voting.pdf Accessed 1 March 2018.

${ }^{52}$ See Avia Pasternak and Emily McTernan, "Political Rioting: A Moral Assessment", forthcoming. 


\begin{abstract}
${ }^{53}$ Terrorism is often associated with coercion, but of the reasons to doubt the justifiability of terrorism, its coerciveness is perhaps one of the lesser ones. See Jeremy Waldron, "Terrorism and the Uses of Terror," The Journal of Ethics 8, no. 1 (2004): 5-35.

${ }^{54}$ This suggests a limitation on at least some of the tactics discussed approvingly by Mathew Humphrey and Marc Stears in "Animal rights protest and the challenge to deliberative democracy." Economy and Society 35.3 (2006): 400-422.

${ }^{55}$ This provides an additional reason to be cautious about violence, which tends to isolate those who use it from the wider community, leading to perilous forms of groupthink and potentially a self-sustaining logic of violent struggle. In his inside story of the Weather Underground, David Gilbert notes how in taking up violent struggle the group cut themselves off from democratic debate, leading the wider movement to suffer division and decline. See Love and struggle: My life in SDS, the weather underground, and beyond. PM Press, 2012.
\end{abstract}

\title{
References
}

Aitchison, Guy. "Three Models of Republican Rights: Juridical, Parliamentary and Populist." Political Studies, 65.2 (2017).

Anderson, Elizabeth S. "What Is the Point of Equality?*," Ethics 109, no. 2 (1999): 287-337. Anderson, Scott A., "Enforcement Approach to Coercion, The," J. Ethics \& Soc. Phil. 5 (2010). Berlin, Isaiah, 'Two Concepts of Liberty', in I. Berlin, Four Essays on Liberty, London: Oxford University Press. New ed. in Berlin 2002.

Brownlee, Kimberley. Conscience and conviction: The case for civil disobedience. OUP Oxford, 2012.

Cabrera, Luis, The Practice of Global Citizenship. Cambridge University Press, 2010. Celikates, Robin. "Rethinking Civil Disobedience as a Practice of Contestation-Beyond the Liberal Paradigm." Constellations 23.1 (2016a).

Celikates, Robin. "Democratizing civil disobedience." Philosophy \& Social Criticism, 42.10 (2016b).

Coffee, Alan MSJ. "Two spheres of domination: Republican theory, social norms and the insufficiency of negative freedom." Contemporary Political Theory 14.1 (2015): 45-62. Crouch, Colin, Post-Democracy (Polity Cambridge, 2004).

Delmas, Candice. "Political resistance: A matter of fairness." Law and Philosophy 33.4 (2014). Gilbert, David, Love and struggle: My life in SDS, the weather underground, and beyond. PM Press, 2012.

Gilens, Martin, and Benjamin I. Page. "Testing theories of American politics: Elites, interest groups, and average citizens." Perspectives on politics 12.3 (2014): 564-581.

Goodwin, Jeff, James M. Jasper, and Francesca Polletta, eds. Passionate politics: Emotions and social movements. University of Chicago Press, 2009.

Gourevitch, Alex. "Quitting work but not the job: Liberty and the right to strike." Perspectives on Politics 14.2 (2016).

Habermas, Jürgen, "Civil Disobedience: Litmus Test for the Democratic Constitutional State," Berkeley Journal of Sociology 30 (1985).

Humphrey, Mathew and Marc Stears in "Animal rights protest and the challenge to deliberative democracy." Economy and Society 35.3 (2006): 400-422.

Lefkowitz, David. "On a moral right to civil disobedience." Ethics 117.2 (2007): 202-233. Livingston, Alexander. "Between Means and Ends: Reconstructing Coercion in Dewey's Democratic Theory." American Political Science Review 111.3 (2017).

Mansbridge, Jane, et al. "The place of self-interest and the role of power in deliberative democracy." Journal of Political Philosophy 18.1 (2010): 64-100. 
Mantena, Karuna. "Another realism: the politics of Gandhian nonviolence." American Political Science Review 106.2 (2012): 455-470.

Markovits, Daniel. "Democratic disobedience." Yale Law Journal 114 (2004).

Medearis, John. Why democracy is oppositional. Harvard University Press, (2015).

Nozick, Robert, 'Coercion', Socratic puzzles. Harvard University Press, 1997.

Olson, Mancur, The Logic of Collective Action, vol. 124 (Harvard University Press, 2009).

Pasternak, Avia and Emily McTernan, "Political Rioting: A Moral Assessment", forthcoming.

Pettit, Philip. On the People's Terms: A Republican Theory and Model of Democracy. Cambridge University Press, 2012.

Rawls, John, A Theory of Justice, (Belknap Press, 1999).

Raz, Joseph, "Civil Disobedience," in The Authority of Law (Oxford: Clarendon Press, 1979).

Singer, Peter, Democracy and Disobedience, vol. 82 (Cambridge University Press, 1973).

Smith, William. Civil disobedience and Deliberative Democracy. Routledge, 2013.

Waldron, Jeremy, "Terrorism and the Uses of Terror," The Journal of Ethics 8, no. 1 (2004): 5-35.

Walzer, Michael, Obligations: Essays on Disobedience, War and Citizenship (Harvard University

Press, 1970).

Warren, Mark E. "Democracy and deceit: regulating appearances of corruption." American Journal of Political Science 50.1 (2006), pp. 165-166.

Wasow, Omar. "Do Protest tactics matter? Evidence from the 1960's black insurgency." Working paper, Princeton University, (2017). Available at:

http://www.omarwasow.com/Protests on Voting.pdf Accessed 1 March 2018.

Watkins, David. "Institutionalizing Freedom as Non-domination: Democracy and the Role of the State." Polity 47.4 (2015): 508-534.

Welchman, Jennifer. "Is ecosabotage civil disobedience?." Philosophy \& Geography 4.1 (2001): 97-107.

Wilks, Stephen, The Political Power of the Business Corporation (Edward Elgar Publishing, 2013). Winters, Jeffrey A. Oligarchy (Cambridge University Press, 2011).

Wong, Julia Carrie, 'Dakota Access pipeline: US denies key permit, a win for Standing Rock protesters', The Guardian, (2016), Available at: https://www.theguardian.com/usnews/2016/dec/04/dakota-access-pipeline-permit-denied-standing-rock (accessed 19 December 2017).

Young, Iris Marion, “Activist Challenges to Deliberative Democracy,” Political Theory, 2001, 67090.

Young, Iris Marion, Inclusion and Democracy (Oxford University Press, 2002).

Young, Kevin and Michael Schwartz, "A Neglected Mechanism of Social Movement Political Influence: The Role of Anticorporate and Anti-Institutional Protest in Changing Government Policy," Mobilization: An International Quarterly 19, no. 3 (2014): 239-60. 